\title{
EVALUATION OF PTEN AND PI3K/AKT EXPRESSIONS IN STANOZOLOL-TREATED RAT KIDNEYS
}

\author{
STANOZOLOL UYGULANAN SIÇAN BÖBREĞINDE PTEN VE PI3K/AKT \\ EKSPRESYONLARININ DEĞERLENDIRILMESI
}

\author{
Tuğba KOTiL' (D), Çiğdem SEVIM² (D), Mehtap KARA ${ }^{3}$ (D) \\ ${ }^{1}$ Istanbul University, Istanbul Faculty of Medicine, Department of Histology and Embryology, Istanbul, Turkey \\ ${ }^{2}$ Atatürk University, Faculty of Veterinary Sciences, Department of Pharmacology and Toxicology, Erzurum, Turkey \\ ${ }^{3}$ Istanbul University, Faculty of Pharmacy, Department of Pharmaceutical Toxicology, Istanbul, Turkey
}

ORCID IDs of the authors: T.K. 0000-0003-1261-0597; Ç.S. 0000-0002-0575-3090; M.K. 0000-0001-7764-5593

Cite this article as: Kotil T, Sevim C, Kara M. Evaluation of PTEN and Pi3k/Akt expressions in stanozolol-treated rat kidneys. J Ist Faculty Med 2022;85(1):59-66. doi: 10.26650/IUITFD.909985

\section{ABSTRACT}

Objective: Stanozolol is an anabolic androgenic steroid (AAS) that is widely used by teenagers and athletes in bodybuilding, sports, and athletics. The potential effects of stanozolol in kidney functions have not been defined. In this study we investigated the expression of tumor suppressor protein phosphatase and tensin homolog (Pten) and mRNA levels of phosphatidylinositol 4,5-bisphosphate 3 kinase (Pi3k) and the protein kinase B (Akt1) signaling pathway in rat kidneys treated by stanozolol.

Materials and Methods: Rats were randomized to 5 groups as control, solvent control, steroid (stanozolol), solvent-exercise, and steroid-exercise. Subcutaneous injection of stanozolol (5 $\mathrm{mg} / \mathrm{kg}$ ) was applied for 28 days and swimming exercise was performed $20 \mathrm{~min} /$ day, 5 days/week in exercise groups. Expression of PTEN was evaluated by immunohistochemistry. Also, Pten, Pi3k, and Akt1 mRNA expressions were analyzed via RT-PCR.

Results: Mesangial cells and renal tubules in the control, solvent control, and solvent exercise groups showed strong (+++) PTEN reactivity against weak PTEN reactivity in the steroid group. Moderate PTEN reactivity was detected in cells of the steroid exercise group. Pten mRNA expression was significantly decreased, and Pi3k and Akt1 mRNA expression were significantly increased in the steroid group versus other groups $(p<0.001)$. Pten expression showed increase while Pi3k and Akt1 expression showed decrease with exercise treatment $(p<0.05)$.

Conclusion: Our findings suggest that AAS usage may inhibit PTEN expression in kidneys, which can be associated with increased Pi3k and Akt1 mRNA levels. Exercise performed with AAS usage can be protective on stanozolol-exposed kidneys due to increased levels of PTEN expression and decreased levels of Pi3k and Akt1.

Keywords: Stanozolol, kidney, PTEN, PI3K, Akt1

\section{ÖZET}

Amaç: Stanozolol, gençler ve sporcular tarafından vücut geliştirme, spor ve atletizmde yaygın kullanımı olan bir anabolik androjenik steroiddir (AAS). Stanozololün böbrek fonksiyonlarındaki potansiyel etkileri tanımlanmamıştır. Bu çalışmada, stanozolol ile tedavi edilen sıçan böbreklerinde tümör baskılayıcı protein fosfotaz tensin homolog (Pten), Phosphatidylinositol-3-kinase (Pi3k) ve protein kinaz B (Akt1)'nin mRNA düzeylerinin ekspresyonunu araştırdık.

Gereç ve Yöntem: Sıçanlar, kontrol, çözücü kontrol, steroid, çözücü kontrol egzersiz, steroid egzersiz olarak 5 gruba ayrıldı. Yirmi sekiz gün boyunca subkutan stanozolol enjeksiyonu (5 mg/ $\mathrm{kg}$ ) uygulandı ve egzersiz gruplarındaki hayvanlara $20 \mathrm{dk} / g u ̈ n$, 5 gün/hafta yüzme egzersizleri yaptırıldı. PTEN ekspresyonu immünohistokimya ile değerlendirildi. Ayrıca Pten, Pi3k ve Akt1 mRNA ekspresyonları RT-PCR yoluyla analiz edildi.

Bulgular: Kontrol, çözücü kontrol ve çözücü kontrol egzersiz gruplarındaki mezanjiyal hücreler ve böbrek tübülleri, steroid grubunda saptanan zayıf PTEN reaktivitesine karşı güçlü (+++) PTEN reaktivitesi gösterdi. Steroid egzersiz grubunun mezanjiyal ve tübül hücrelerinde orta düzeyde PTEN reaktivitesi saptandı. Pten mRNA ekspresyonu, steroid grubunda kontrol ve diğer gruplara göre anlamlı düşüş gösterdi, Pi3k ve Akt1 mRNA ekspresyonu anlamlı olarak arttı ( $p<0.001)$. Egzersiz tedavisi ile Pten ekspresyonu artış, Pi3k ve Akt1 ekspresyonu azalma gösterdi $(p<0.05)$.

Sonuç: Bulgularımız, AAS kullanımının, artan Pi3k ve Akt1 mRNA seviyeleri ile ilişkili olabilecek böbreklerde PTEN ekspresyonunu inhibe edebileceğini düşündürmektedir. AAS kullanımı ile yapılan egzersiz, PTEN ekspresyon seviyelerinin artması ve Pi3k ve Akt1 seviyelerinin düşmesi nedeniyle stanozolole maruz kalan böbrekler üzerinde koruyucu olabilir.

Anahtar Kelimeler: Stanozolol, böbrek, PTEN, PI3K, Akt1

Corresponding author/iletişim kurulacak yazar: tkotil@istanbul.edu.tr

Submitted/Başvuru: 12.04.2021 • Revision Requested/Revizyon Talebi: 24.05.2021 • Last Revision Received/Son Revizyon: 28.07.2021 • Accepted/Kabul: 13.08.2021 • Published Online/Online Yayın: 06.01.2022 


\section{INTRODUCTION}

Anabolic androgenic steroids (AAS), which are synthetic testosterone derivatives, exert their androgenic effects via enhancing anabolic activity. These effects cause increases in muscle growth and strength, improving athletic performance. AASs are prescribed for hypogonadism. They prevent muscle mass loss during medical use, however, these types of chemicals are used by non-expert athletes due to their anabolic effects (1-3). An abusive dose of AAS is 10-100 times higher than its pharmacological dose. These higher doses cause several adverse effects that include hepatotoxicity, reproductive system problems, cardiovascular problems, psychiatric and behavioral disorders, and cancer (4). It has been documented that AASs have different types of adverse effects, such as acute kidney injury, chronic kidney diseases, glomerular toxicity, etc., in kidneys (5). One of the adverse effects of AAS misuse is renal failure in bodybuilders and athletes $(6,7)$. It has been reported that an increase in athletes' serum creatinine levels may be due to AAS abuse. Serum creatinine, blood urine nitrogen (BUN), and uric acid levels can increase through steroid use (8). In some cases, Wilm's tumor development was reported in athletes (9). It has been reported that administration of stanozolol can cause renal failure in some cases. Stanozolol is a C17 $\alpha$-alkylated derivative of testosterone and is used as an AAS $(3,4,10-13)$.

The PTEN/PI3K/AKT1 pathway is an important modulator of cell proliferation and cell death (14). The PTEN/PI3K/ AKT1 signaling inhibition suppresses cellular adhesion and induces apoptosis (15). Tumor suppressor PTEN (the phosphatase and tensin homolog gene) dysfunction has an important role in different types of cancer. Mutations, deletions, and protein folding disruptions may cause PTEN function loss. PTEN dysfunction negatively affects the phosphoinositide 3-kinase (PI3K) signaling pathway that causes phosphatidylinositol (3-5)-triphosphate accumulation. These accumulations result in inhibition of the PI3K/AKT1 pathway (16). In different studies and case reports it has been reported that AASs cause kidney failure, however, the potential effects of stanozolol in kidney functions have not been evaluated. It has been known that exercise has benefits in the whole-body system and regular exercise activity has a preventive role against kidney cancer $(17,18)$.
In this study, we aimed to clarify the effects of stanozolol on the expression of the tumor suppressor protein PTEN and the levels of Pten, Pi3k, and Akt1 mRNA in rat kidneys, and also if there is a potential protective effect of exercise on kidneys.

\section{MATERIALS AND METHODS}

\section{Animal study}

Study procedures were approved by the Istanbul University Institutional Animal Care and Use Committee (protocol number of Animals Ethics approval: HADYEK; 2013-100). Thirty-four 8 month-old, 230 gr. Sprague Dawley rats were used in this study. The animals were divided into 5 groups: group I - control group ( $n=5)$, group II - solvent (propylene glycol) control $(n=5)$, group III - steroid (stanozolol $5 \mathrm{mg} /$ $\mathrm{kg})(\mathrm{n}=8)$, group IV - solvent exercise $(n=8)$, group $V$ - steroid exercise $(n=8)$. Subcutaneous injections of stanozolol $(5 \mathrm{mg} / \mathrm{kg})$ and vehicle propylene glycol $(1 \mathrm{ml} / \mathrm{kg})$ were applied for 28 days, once a day. Through the experiments, swimming exercise was applied to the exercise groups for 20 minute a day, 5 days/week. After animal scarification under anesthesia, one of the kidneys was fixed with $10 \%$ neutral buffered formalin and the other was stored at $-80^{\circ} \mathrm{C}$ after being frozen with liquid nitrogen.

\section{Total RNA extraction and cDNA synthesis}

Twenty mg tissue samples obtained from animals were incubated with RNA Stabilization Reagent (RNAlater; Qiagen), then TissueLyser II (Qiagen) was added. RNA purification was performed with RNeasy Mini Kit (Qiagen) in QlAcube (Qiagen) and the manufacturer's instructions were followed. Reverse transcription to cDNA was performed with a High-Capacity cDNA Reverse Transcription Kit (Applied Biosystems, Foster City, CA, USA). cDNA quality was assessed with an Epoch Spectrophotometer System and Take3 Plate (BioTek, Winooski, VT, USA).

\section{Relative quantification of the gene expression}

StepOnePlus Real-Time PCR System technology (Applied Biosystems) was used to evaluate Pten, Pi3k, and Akt1 mRNA expression analyses with TaqMan Probebased technology (Primer Design Ltd., Southampton, UK). Study results were shown as relative fold increase/ decrease compared with the control animals using the 2- ${ }^{\Delta \Delta C t}$ method (Livak, KJ and Schmittgen, TD). The primer sequences are shown in Table 1. All assays were done in triplicate and on three different days. For each sample, $100 \mathrm{ng}$ cDNA was added into the PCR mix with $1 \mu \mathrm{L}$ of

Table 1: The primer sequences for real time PCR

\begin{tabular}{|c|c|c|c|}
\hline Gene & Forward $\left(5^{\prime}-3^{\prime}\right)$ & Reverse $\left(5^{\prime}-3^{\prime}\right)$ & Assay ID \\
\hline Pten & TTGGCGGTGTCATAATGTCT & GCAGAAAGACTTGAAGGCGTA & Rn00477208 \\
\hline Pi3k & AACACAGAAGACCAATACTC & TTCGCCATCTACCACTAC & Rn01769524 \\
\hline Akt1 & GTGGCAAGATGTGTATGAG & CTGGCTGAGTAGGAGAAC & Rn00583646 \\
\hline$\beta$-actin & TGGTGGGTATGGGTCAGAAG & GACAATGCCGTGTTCAATGG & Rn00667869 \\
\hline
\end{tabular}


Primer Perfect Probe and QuantiTect Probe PCR Master mix (Qiagen). Beta-actin was used as a reference. Total reaction mix was $20 \mu \mathrm{L}$ for each sample. The cycle procedure was heating for $2 \mathrm{~min}, 95^{\circ} \mathrm{C}$ for $10 \mathrm{~min}$, then 40 cycles of $15 \mathrm{sec}$. at $94^{\circ} \mathrm{C}$ and $60 \mathrm{sec}$. at $60^{\circ} \mathrm{C}(19)$.

\section{Immunohistochemistry}

PTEN expression was evaluated by the immunohistochemistry method. Kidney tissues were fixed with 10\% formaldehyde and embedded in paraffin. Sections from the paraffin block (approximately 2-3 $\mu \mathrm{m}$ ) were taken with a microtome and emplaced on charged microscope slides. After overnight incubation at $56^{\circ} \mathrm{C}$, sections passed one by one decreasing alcohol series for the rehydration process. Then sections were incubated in 5\% hydrogen peroxide (in methanol) for $15 \mathrm{~min}$. for blockage of endogen peroxidase. Sections were washed with PBS. $10 \%$ citrate buffer incubation in a microwave was performed 3 times for $5 \mathrm{~min}$ for the antigen retrieval process. After cooling of sections, 1/100 diluted PTEN primary antibody (Abbiotec 251264) was added onto sections and incubated overnight at $+4^{\circ} \mathrm{C}$. Then sections were washed with PBS and subsequently biotin-labeled secondary antibody and DAB chromogen solutions were performed for 10 min each. After washing with distillated water, sections were dyed with Mayer's hematoxylin for 30 seconds.
Then sections were washed with tap water, covered with coverglass, and scored under light microscopy. In the immunohistochemistry evaluation, the tissue samples of each animal were examined and the data were evaluated. PTEN antibody staining intensity was scored according to the overall intensity with 3 levels ( $+=$ weak staining; $++=$ moderate staining; and $+++=$ strong staining).

\section{Statistical analysis}

We used SPSS version 20 software (IBM Corp., Armonk, NY, USA) for statistical analyses for gene expression evaluation only between all 6 groups. Mean value and standard deviation were calculated. Comparison of means was performed by ANOVA one-way analysis of variance and the Tukey test. Differences were considered significant if $p<0.05$.

\section{RESULTS}

\section{Gene expression}

The gene expression levels of all groups are summarized in Table 2. In our study, upon completion of the treatment, the expression of Pten, Pi3k, and Akt1 mRNA was measured using RT-PCR. Pten mRNA expression downregulated significantly in the steroid group $(p<0.05)$ compared to other experimental groups. In the steroid exercise group, Pten upregulated significantly compared to the steroid group $(p<0.001)$ (Figure 1). A significant in-

Table 2: Gene expression levels of treated animal groups

\begin{tabular}{lcccccc}
\hline & \multicolumn{2}{c}{ PTEN } & \multicolumn{2}{c}{ PI3K } & AKT \\
& Mean & SD & Mean & SD & Mean & SD \\
Groups & & & & & & \\
Control & 2.02 & \pm 0.28 & 1.37 & \pm 0.13 & 1.29 & \pm 0.17 \\
Solvent control & 1.78 & \pm 0.21 & 1.41 & \pm 0.26 & 1.58 & \pm 0.22 \\
Steroid & 0.57 & \pm 0.03 & 3.04 & \pm 0.48 & 3.21 & \pm 0.39 \\
Solvent exercise & 2.17 & \pm 0.31 & 1.46 & \pm 0.23 & 1.19 & \pm 0.16 \\
Steroid exercise & 1.3 & \pm 0.18 & 2.05 & \pm 0.3 & 2.26 & \pm 0.24 \\
\hline
\end{tabular}

PTEN: phosphatase and tensin homolog, PI3K: phosphoinositide 3-kinase, AKT: protein kinaz B, SD: Standard deviation

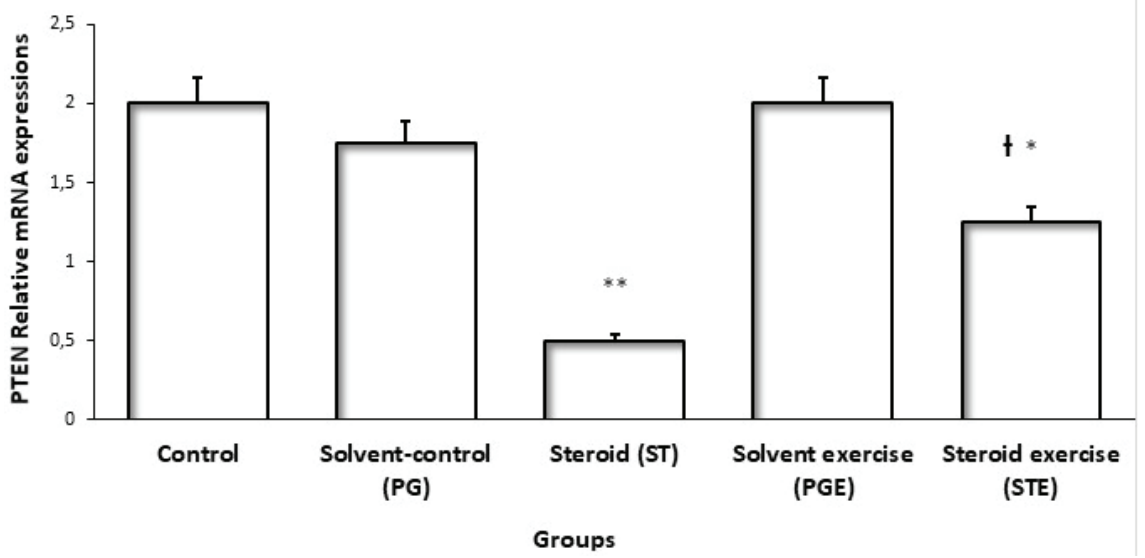

Figure 1: Compares the Pten mRNA expression levels. Significant changes steroid versus other groups ( $\left.{ }^{\star *} p<0.05\right)$, and steroid exercise versus steroid group $\left({ }^{\star} p<0.001\right)$, steroid exercise versus other groups ( $\mathrm{xp}<0.001)$. 
crease in Pi3k mRNA expression was seen in the steroid group compared to other groups $(p<0.05)$. A significant increase in Pi3k mRNA expression was also seen in the steroid exercise group compared with the control, solvent control, and solvent exercise groups $(p<0.001)$, but decrease was detected compared with the steroid group $(p<0.001)$ (Figure 2). The steroid treatment group led to a significant increase in Akt1 mRNA expression compared with the other groups $(p<0.05)$. The steroid exercise treatment group led to a significant increase in Akt1 mRNA expression compared with the control, solvent control, and solvent exercise groups $(p<0.001)$ but decreased compared with the steroid group $(p<0.001)$ (Figure 3$)$.

\section{Immunohistochemistry}

The results of the PTEN immunoreactivity are summarized in Table 3. Similar reactivity was detected in light

Table 3: PTEN immunohistochemistry reactivity scoring

\begin{tabular}{lccccc}
\hline Pten reactivity & Control & Solvent control & Steroid & Solvent exercise & Steroid exercise \\
Proximal tubules & - & - & - & - & - \\
Distal tubules & +++ & +++ & + & ++ & ++ \\
Mesangial cells & +++ & +++ & - & +++ & - \\
Medullar tubules & ++ & ++ & + & ++ & ++ \\
\hline
\end{tabular}

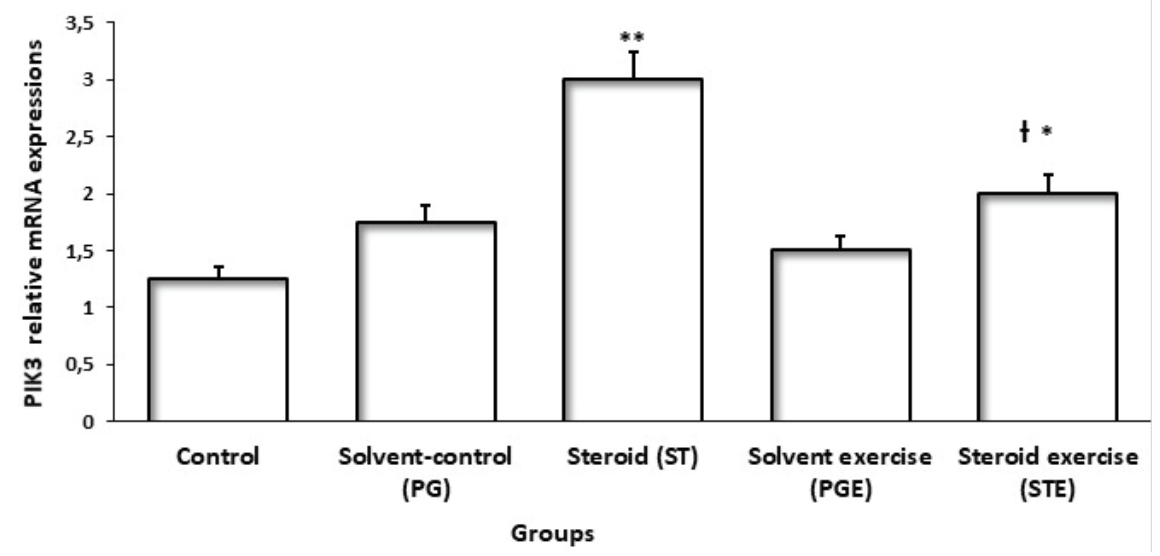

Figure 2: Compares the Pi3k mRNA expression levels. Significant changes steroid versus other groups $\left({ }^{* *} p<0.05\right)$, and steroid exercise versus steroid group $\left({ }^{*} p<0.001\right)$, steroid exercise versus other groups ( $\left.\mathrm{x} p<0.001\right)$.

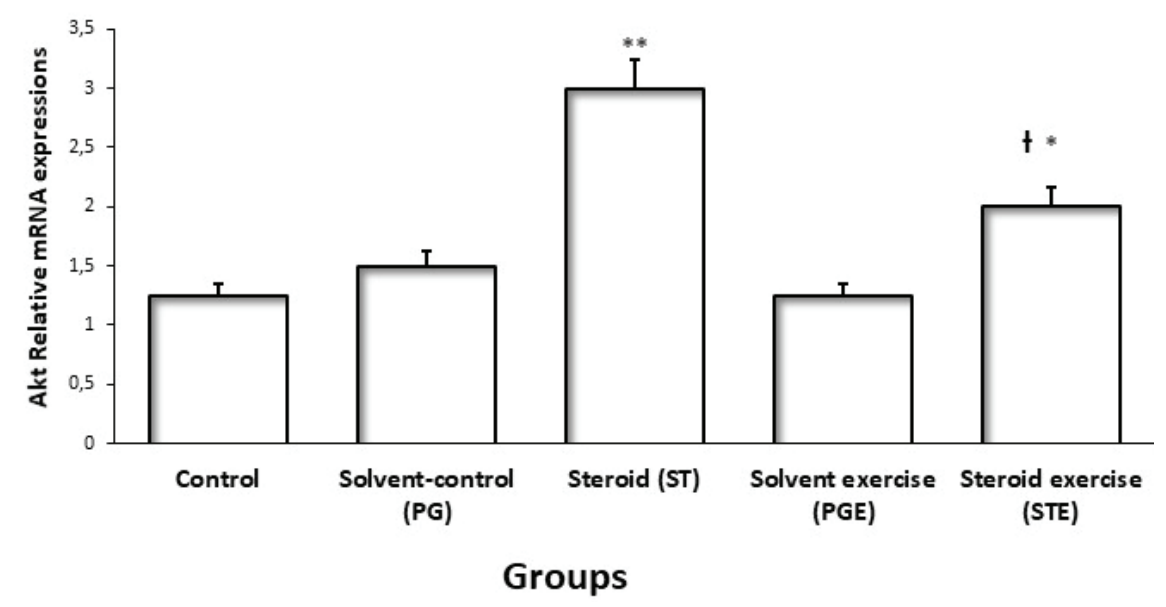

Figure 3: Compares the Akt1 mRNA expression levels. Significant changes steroid versus other groups $\left({ }^{\star \star} p<0.05\right)$, and steroid exercise versus steroid group $\left({ }^{\star} p<0.001\right)$, steroid exercise versus other groups $(\mathrm{x} p<0.001)$. 
microscopic evaluation of the control, solvent control, and solvent exercise groups. In these groups, glomerular mesangial cells had a strong (+++) PTEN reaction. Cells of distal tubules had strong $(+++)$ immunoreactivity but proximal tubules did not show any reaction. Tubules of medulla showed a moderate $(++)$ reaction. In the steroid-treated group, mesangial cells and proximal tubule cells did not show PTEN immunoreactivity. A few distal tubules showed weak $(+)$ reaction. Medullary tubules also had weak (+) immunoreactivity. In the steroid exercise group, no immunoreactivity was detected in mesangial cells or proximal tubules. But moderate $(++)$ reaction in distal tubules and medullary tubules was detected (Figure 4).

\section{DISCUSSION}

Synthetic AAS Stanozolol is a substance that has functions like testosterone. This chemical is used to enhance athletic performance and improve aesthetics (20). Higher doses of AAS can cause several types of adverse effects on the cardiovascular system, reproductive system, urinary system, and hepatic system, and mental health problems (21). AAS mimics testosterone's physiological effect by inducing an altered expression on DNA sequences. Reports showed a close relationship between AASs and cancer formation, progression, and metastases. The metabolites of AASs are inducers of cell proliferation. Like testosterone, AASs are metabolized to 17 beta-estradiol and play an important role in estrogen-dependent can-
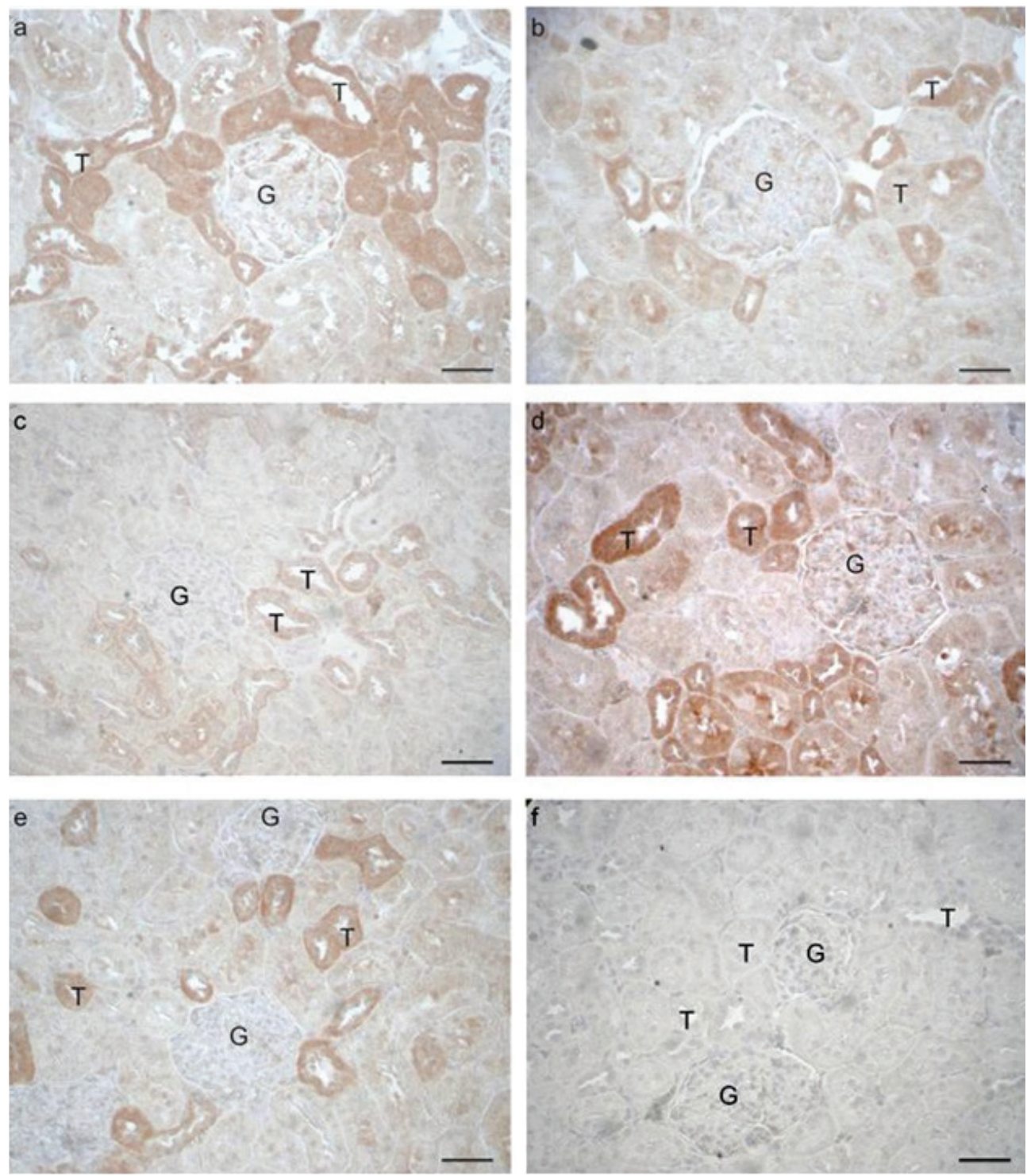

Figure 4: PTEN immunoreactivity, a) Control group, b) solvent control group, c) steroid group, d) solvent exercise group, e) steroid exercise group, G: Glomerulus, T: tubules 
cer mechanisms. Additionally, reactive oxygen species (ROS) are increased during AASs catabolism. This can cause genotoxicity and the formation of adenomas (2225). The misuse of AASs can cause kidney toxicity and increased kidney cancer formation risk $(12,26,27)$. Chronic AAS usage can promote apoptosis via oxidative stress in kidney tissue. It has also been reported that AASs induce genetic damage in kidney tissue (27-29). Pak et al. reported that the kidney carcinogenesis mechanism could be triggered by AAS usage through the STAT5 pathway (26). However, AASs' adverse effects on kidney tissue have not been clarified yet. The adverse effects of stanozolol on kidneys have been evaluated in different studies. An excessive dose of stanozolol increased the serum creatinine levels, and induced oxidative stress $(4,10)$.

One of the major regulating molecular mechanisms of cell proliferation and survival is the PTEN/PI3K/AKT1 pathway. AKT1 is an anti-apoptotic factor and its overexpression causes cell cycle arrest and inhibition of cellular death. AKT1 regulates the apoptosis mechanism via inactivating the pro-apoptotic proteins. Alterations in this pathway are associated with several diseases, including cancer. It has been shown that PI3K/AKT1 signaling is disrupted in many cancer types, such as breast cancer, colon cancer, ovarian cancer, pancreatic cancer, and prostate cancer. PTEN inactivation is associated with AKT1 activation, which causes tumor cell proliferation. PTEN function loss might be the cause of mutation, deletion, or epigenetic modulations at high frequency in many primary and metastatic human cancers $(30,31)$.

Mutations of the PTEN gene and disrupted expression of PTEN were reported in several studies. Nassif et al., reported the reduced or absent immunohistochemical reaction of PTEN in primary sporadic colorectal cancer (32). Also, immunohistochemical and RT-PCR analysis has shown a complete loss of PTEN mRNA expression in anaplastic thyroid cancers (33). Wang et al. reported mutations in PTEN genes in late-stage bladder carcinoma, and Wu et al. also showed loss of PTEN expression in melanoma $(34,35)$. Kanamori et al. reported a negative correlation between PTEN and AKT1 expression in endometrial carcinoma cells (36). Breuksch et al. demonstrated that PTEN function loss can play a role in kidney tumor progression (37). In our study, we detected loss of PTEN expression in mesangial cells and cells of kidney tubules due to stanozolol treatment. Our results are consistent with the referenced literature. Several studies reported that androgens and AASs can cause cell proliferation and survival due to the activation of the PI3K/AKT pathway. Sirianni et al. evaluated the effects of nandrolone and stanozolol on breast cancer cell proliferation and detected increased AKT1 phosphorylation and stimulation of the PI3K/AKT1 and PLC/ PKC pathways (38). It has been reported that androgens stimulate ovarian cancer cell survival via telomerase activity and the PI3K/AKT1 pathway (39). In our study, the steroid-treated group showed increased mRNA expression of Pi3k and Akt1. This increased activation of Pi3k/ Akt1 expression is associated with decreased Pten expression.

Also, in the steroid exercise group, we detected increased expression of Pten with the decreased expression of Pi3k and Akt1 against the steroid group. Physical inactivity is related to cancer development. Recent studies showed that physical activity is effective in reducing the risk of various cancers like pancreatic, colon, prostate, lung, ovarian, breast, and endometrial (40-42). Yu et al. have reported that exercise increased the Pten expression levels of mice skin cells compared with a sedentary control group and prevented the risk of skin cancer development. Also, benefits of regular exercise on the development of hepatocellular carcinoma were reported (43). There is no reported article about the protective effects of exercise on kidneys. Our findings suggest that exercise may have a protective effect on kidneys exposed to stanozolol.

As a result of our findings, we suggest that stanozolol usage can cause possible renal cancer development via decreased Pten expression and the increased Pi3k/Akt1 pathway. According to our results, the Pten gene expression profile was in accordance with PTEN immunohistochemistry results. Daily exercise during AAS treatment may be beneficial to kidney health and can decrease the risk of cancer development. In this study, the inability to evaluate the parameters associated with kidney dysfunction in the blood in animals and the inability to examine the expression levels of genes and proteins belonging to more molecular pathways in the kidney are limiting factors. In conclusion, in more detailed and long-term chronic studies, the correlation between the Pten gene and protein expression levels will be investigated and even more molecular pathway elements can be evaluated.

Informed Consent: Written consent was obtained from the participants.

Ethics Committee Approval: Ethics committee approval was received for this study from the Istanbul University Animal Experiments Local Ethics Committee (Date: 30.09.2013, No: 100).

Peer Review: Externally peer-reviewed.

Author Contributions: Conception/Design of Study-Ç.S., M.K.; Data Acquisition- T.K., Ç.S., M.K.; Data Analysis/InterpretationT.K., Ç.S., M.K.; Drafting Manuscript- T.K., Ç.S., M.K.; Critical Revision of Manuscript-T.K.,M.K.; Approval and AccountabilityT.K., Ç.S., M.K.

Conflict of Interest: Authors declared no conflict of interest 
Financial Disclosure: The present study was supported by Istanbul University Scientific Research Projects Department (project no. 39101-21899).

\section{REFERENCES}

1. Bhasin S, Storer TW, Berman N, Yarasheski KE, Clevenger B, Phillips J, et al. Testosterone replacement increases fat-free mass and muscle size in hypogonadal men. J Clin Endocrinol Metab 1997;82(2):407-13. [CrossRef]

2. Yesalis CE, Bahrke MS. Anabolic-androgenic steroids and related substances. Curr Sports Med Rep 2002;1(4):246-52. [CrossRef]

3. Lionikas A, Blizard DA. Diverse effects of stanozolol in C57BL/6J and A/J mouse strains. Eur J Appl Physiol 2008;103(3):333-41. [CrossRef]

4. Dornelles GL, Bueno A, de Oliveira JS, da Silva AS, França RT, da Silva $C$, et al. Biochemical and oxidative stress markers in the liver and kidneys of rats submitted to different protocols of anabolic steroids. Molecular And Cellular Biochemistry 2017;425(1-2):181-9. [CrossRef]

5. Davani-Davari D, Karimzadeh I, Khalili H. The potential effects of anabolic-androgenic steroids and growth hormone as commonly used sport supplements on the kidney: a systematic review. BMC Nephrology 2019;20(1):198. [CrossRef]

6. Almukhtar SE, Abbas AA, Muhealdeen DN, Hughson MD. Acute kidney injury associated with androgenic steroids and nutritional supplements in bodybuilders. Clin Kidney J 2015;8(4):415-9. [CrossRef]

7. Daher EDF, Fernandes PHPD, Meneses GC, Bezerra GF, Ferreira LDSL, Viana GBD, et al. Novel kidney injury biomarkers among anabolic androgenic steroids usersevidence of subclinical kidney disease. Asian J Sports Med 2018;9(1):e65540. [CrossRef]

8. Juhn M. Popular sports supplements and ergogenic aids. Sports Med 2003;33(12):921-39. [CrossRef]

9. Maravelias C, Dona A, Stefanidou M, Spiliopoulou C. Adverse effects of anabolic steroids in athletes. A constant threat. Toxicol Lett 2005;158(3):167-75. [CrossRef]

10. Yoshida EM, Karim MA, Shaikh JF, Soos JG, Erb SR. At what price, glory? Severe cholestasis and acute renal failure in an athlete abusing stanozolol. CMAJ 1994;151(6):791-3.

11. Habscheid W, Abele U, Dahm HH. Schwere Cholestase mit Nierenversagen durch Anabolika bei einem Bodybuilder [Severe cholestasis with kidney failure from anabolic steroids in a body builder]. Dtsch Med Wochenschr 1999;124(36):1029-32. [CrossRef]

12. Merino García E, Borrego Utiel FJ, Martínez Arcos MÁ, Borrego Hinojosa J, Pérez Del Barrio MP. Kidney damage due to the use of anabolic androgenic steroides and practice of bodybuilding. Nefrologia 2018;38(1):101-3. [CrossRef]

13. Tabatabaee SM, Elahi R, Savaj S. Bile cast nephropathy due to cholestatic jaundice after using stanozolol in 2 amateur bodybuilders. Iran J Kidney Dis 2015;9(4):331-4.

14. Pérez-Ramírez C, Cañadas-Garre M, Molina MÁ, FausDáder MJ, Calleja-Hernández MÁ. PTEN and PI3K/ AKT in non-small-cell lung cancer. Pharmacogenomics 2015;16(16):1843-62. [CrossRef]
15. Zhang J, Li L, Peng Y, Chen Y, Lv X, Li S, et al. Surface chemistry induces mitochondria-mediated apoptosis of breast cancer cells via PTEN/PI3K/AKT signaling pathway. Biochim Biophys Acta Mol Cell Res 2018;1865(1):172-85. [CrossRef]

16. Kim DH, Suh J, Surh YJ, Na HK. Regulation of the tumor suppressor PTEN by natural anticancer compounds. Ann N Y Acad Sci 2017;1401(1):136-49. [CrossRef]

17. Luan X, Tian X, Zhang H, Huang R, Li N, Chen P, et al. Exercise as a prescription for patients with various diseases. J Sport Health Sci 2019;8(5):422-41. [CrossRef]

18. Tahbaz R, Schmid M, Merseburger AS. Prevention of kidney cancer incidence and recurrence: lifestyle, medication and nutrition. Curr Opin Urol 2018;28(1):62-79. [CrossRef]

19. Livak KJ, Schmittgen TD. Analysis of relative gene expression data using real-time quantitative PCR and the 2(-Delta Delta C(T)) method. Methods 2001;25(4):402-8. [CrossRef]

20. Vieira TM, Rossi Junior WC, Da Ré Guerra F, Damião B, Marques PP, Esteves A. Effect of testosterone cypionate and stanozolol on the heart of young trained mice: A morphometric study. Steroids 2019;145:19-22. [CrossRef]

21. Tucci P, Morgese MG, Colaianna M, Zotti M, Schiavone S, Cuomo $V$, et al. Neurochemical consequence of steroid abuse: stanozolol-induced monoaminergic changes. Steroids 2012;77(3):269-75. [CrossRef]

22. Liehr JG. Is estradiol a genotoxic mutagenic carcinogen? Endocr Rev 2000;21(1):40-54. [CrossRef]

23. Giannitrapani L, Soresi M, La Spada E, Cervello M, D'Alessandro N, Montalto G. Sex hormones and risk of liver tumor. Ann N Y Acad Sci 2006;1089:228-36. [CrossRef]

24. Souza LD, da Cruz LA, Cerqueira EM, Meireles J. Micronucleus as biomarkers of cancer risk in anabolic androgenic steroids users. Hum Exp Toxicol 2017;36(3):30210. [CrossRef]

25. Salerno M, Cascio O, Bertozzi G, Sessa F, Messina A, Monda $V$, et al. Anabolic androgenic steroids and carcinogenicity focusing on Leydig cell: a literature review. Oncotarget 2018;9(27):19415-26. [CrossRef]

26. Pak S, Kim W, Kim Y, Song C, Ahn H. Dihydrotestosterone promotes kidney cancer cell proliferation by activating the STAT5 pathway via androgen and glucocorticoid receptors. J Cancer Res Clin Oncol 2019;145(9):2293-301. [CrossRef]

27. Tsitsimpikou C, Vasilaki F, Tsarouhas K, Fragkiadaki P, Tzardi M, Goutzourelas N, et al. Nephrotoxicity in rabbits after long-term nandrolone decanoate administration. Toxicol Lett 2016;259:21-7. [CrossRef]

28. Pozzi R, Fernandes KR, de Moura CF, Ferrari RA, Fernandes KP, Renno AC, et al. Nandrolone decanoate induces genetic damage in multiple organs of rats. Arch Environ Contam Toxicol 2013;64(3):514-8. [CrossRef]

29. Riezzo I, Turillazzi E, Bello S, Cantatore S, Cerretani D, Di Paolo $\mathrm{M}$, et al. Chronic nandrolone administration promotes oxidative stress, induction of pro-inflammatory cytokine and TNF- $\alpha$ mediated apoptosis in the kidneys of CD1 treated mice. Toxicol Appl Pharmacol 2014;280(1):97106. [CrossRef]

30. Osaki M, Oshimura M, Ito H. PI3K-Akt pathway: its functions and alterations in human cancer. Apoptosis. 2004;9(6):66776. [CrossRef] 
31. Xu N, Lao Y, Zhang Y, Gillespie DA. Akt: a double-edged sword in cell proliferation and genome stability. J Oncol 2012;2012:951724. doi: 10.1155/2012/951724. [CrossRef]

32. Nassif NT, Lobo GP, Wu X, Henderson CJ, Morrison CD, Eng $C$, et al. PTEN mutations are common in sporadic microsatellite stable colorectal cancer. Oncogene 2004;23(2):617-28. [CrossRef]

33. Frisk T, Foukakis T, Dwight T, Lundberg J, Höög A, Wallin $G$, et al. Silencing of the PTEN tumor-suppressor gene in anaplastic thyroid cancer. Genes Chromosomes Cancer 2002;35(1):74-80. [CrossRef]

34. Wang DS, Rieger-Christ K, Latini JM, Moinzadeh A, Stoffel J, Pezza JA, et al. Molecular analysis of PTEN and MXI1 in primary bladder carcinoma. Int J Cancer 2000;88(4):620-5. [CrossRef]

35. Wu H, Goel V, Haluska FG. PTEN signaling pathways in melanoma. Oncogene 2003;22(20):3113-22. [CrossRef]

36. Kanamori $Y$, Kigawa J, Itamochi $H$, Shimada M, Takahashi M, Kamazawa $S$, et al. Correlation between loss of PTEN expression and Akt phosphorylation in endometrial carcinoma. Clin Cancer Res 2001;7(4):892-5.

37. Breuksch I, Welter J, Bauer HK, Enklaar T, Frees S, Thüroff JW, et al. In renal cell carcinoma the PTEN splice variant PTEN- $\triangle$ shows similar function as the tumor suppressor PTEN itself. Cell Commun Signal 2018;16(1):35. [CrossRef]

38. Sirianni R, Capparelli C, Chimento A, Panza S, Catalano S, Lanzino $\mathrm{M}$, et al. Nandrolone and stanozolol upregulate aromatase expression and further increase IGF-I-dependent effects on MCF-7 breast cancer cell proliferation. Mol Cell Endocrinol 2012;363(1-2):100-10. [CrossRef]
39. Nourbakhsh M, Golestani A, Zahrai M, Modarressi MH Malekpour Z, Karami-Tehrani F. Androgens stimulate telomerase expression, activity and phosphorylation in ovarian adenocarcinoma cells. Mol Cell Endocrinol 2010;330(1-2):10-6. [CrossRef]

40. Friedenreich CM, Neilson HK, Lynch BM. State of the epidemiological evidence on physical activity andcancer prevention. Eur J Cancer 2010;46:2593-604. [CrossRef]

41. Winzer BM, Whiteman DC, Reeves MM, Paratz JD. Physical activity and cancer prevention: A system-atic review of clinical trials. Cancer Causes Control 2011;22:811-26. [CrossRef]

42. Yu M, King B, Ewert E, Su X, Mardiyati N, Zhao Z, et al. Exercise activates p53 and negatively regulates IGF-1 pathway in epidermis within a skin cancer model. PLoS ONE 2016;11(8):e0160939. doi: 10.1371/journal.pone.0160939. [CrossRef]

43. Piguet AC, Saran U, Simillion C, Keller I, Terracciano L, Reeves $\mathrm{HL}$, et al. Regular exercise decreases liver tumors development in hepatocyte-specific PTEN-deficient mice independently of steatosis. J Hepatol 2015;62(6):1296-303. [CrossRef] 